\title{
ROMAN GRAVESTONE WITH A RIDER SCENE RECOVERED FROM BÖLCSKE
}

\author{
ERNŐ SZABÓ \\ University of Pécs \\ Rókus Str. 2, Building M, H-7624 Pécs, Hungary \\ szabo.erno@pte.hu
}

\begin{abstract}
In this paper, the author publishes a Roman funerary stela from Bölcske found in 2015. Only two highly fragmentary rows have survived of its inscription. The execution of the stela (proportions, arrangement, the framing of fields) and the rider scene of the relief field provide more information than the incomplete funerary inscription: based on three analogous tombstones belonging to soldiers of the ala Frontoniana, one may assume that the person mentioned on the Bölcske gravestone had also served in this unit. Unit history, style analysis arguments and palaeographical reasons all point toward the dating of the monument to the early reign of Emperor Trajan.
\end{abstract}

Keywords: Roman Pannonia, epigraphy, rider type gravestone, Bölcske, ala Frontoniana

During the spring of 2015 Bálint Varga, a local historian from Bölcske, spotted a fragmented stone on the roadside ${ }^{1}$ showing a carved Roman inscription, in the outskirts of the town called Kövesszállás (,Stony billets” in Hungarian). ${ }^{2}$ Numerous archaeological finds were recovered from the area around Kövesszállás even today. ${ }^{3}$ Locals call the stones of this hard-to-plough area „manure of the neighbour" ${ }^{\prime 4}$ as they are often flung over to neighbouring fields. The fragmentary Roman stela discussed in this paper was presumably drawn to the side of the arable land in a similar manner. It is currently displayed in the garden of its rescuer along with further Roman fragmentary monuments, ${ }^{5}$ where I have had the chance to study it in person in April 2017. ${ }^{6}$

It is a fragment of a limestone funerary stela, measuring $(95) \times(40) \times 28 \mathrm{~cm}$. It was originally the upper left part of a monument (viewed from its front), and its right side and bottom part is missing. The preserved part is broken into two pieces.

The top of the stela finished in a free standing tympanon, of which only approximately its left third has survived. The even edges of the fronton are bound by a double profiled frame, while the fields of the stela are joined together by its undecorated border, thus the architrave also is unadorned.

Of the main scene showing a rider, sunken below the tympanon, the posterior part of the right facing horse has survived, along with the (plausibly right) hand of the horseman thrusting a spear (hasta) or throwing a javelin

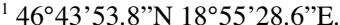

${ }^{2}$ Kövesszállás is an uneven ploughland located between the Szent András Otthon (Saint Andrew's Home) at Szentandráspuszta, Meszesköz, a gravel road leading there and the railway line. Szentandráspuszta is made up of Alsó- (Lower), Felső- (Upper) and Középsőpuszta (Middle). Udvari 1994, 410, 415.

${ }^{3}$ SOPRONI 1990, 139-140; PÉTERFI 1993, 32; SZABÓ-SZÉCSI 1994, 86-88, nr. 120, 124-126; VISY 2000, 83 = VISY 2003, 89-90.

\footnotetext{
${ }^{4}$ UDVARI 1994, 410.

${ }^{5}$ A fragment of an altar was published by P. Kovács (KovÁcs 2014) as well as the relief fragments of the relief field of two funerary stelae.

${ }^{6} \mathrm{I}$ hereby wish to express my thanks to archaeologist and head museologist Géza Szabó PhD for calling my attention to this inscribed stone fragment.
} 

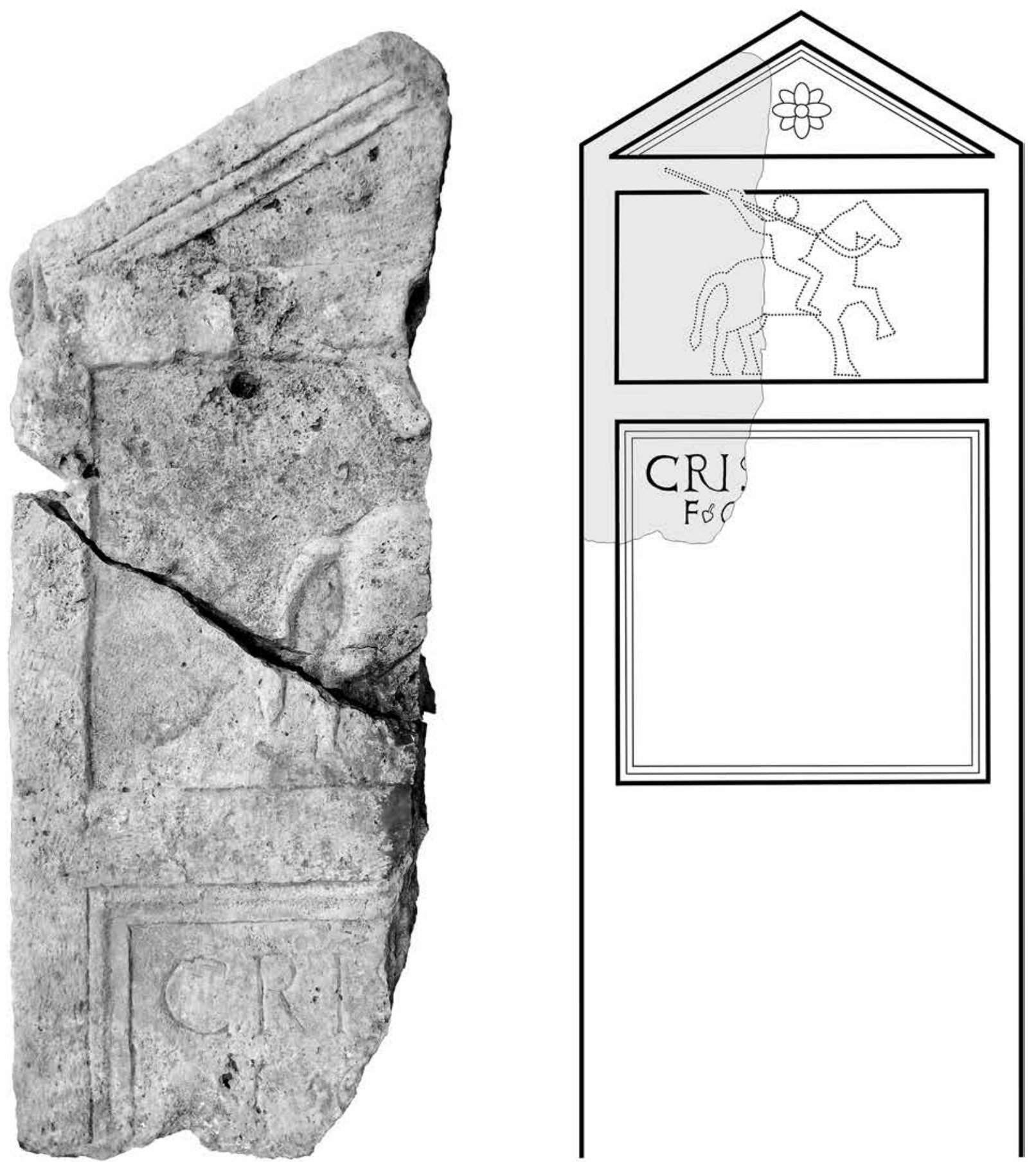

Fig. 1. The fragmentary stela from Bölcske and its reconstruction (photo and reconstruction: E. Szabó)

(iaculum). The section of the weapon, ${ }^{7}$ aimed at the bottom right corner that was above the hand, was incised into the upper frame (architrave). Surviving details do not enable us to determine whether the scene depicts a standing, pacing or jumping horse. The rendering of its hindlegs and relaxed tail infers neither calm pacing nor a standing

${ }^{7}$ Hungarian researchers often identify the long shafted and iron tipped cavalry assault weapon as a pilum, although pila were exclusively used by infantry: UBL 2013, 187-191, with further bibliography. The fragmentary condition of the Bölcske stela prevents settling whether the rider was throwing his weapon (which would render Acta Archaeologica Academiae Scientiarum Hungaricae 71, 2020 it a javelin or iaculum) or thrusting it downwards (making it a spear or hasta). Both interpretations require similar motion, thus uncertainty prevails even in case of completely survived rider scenes. Regarding the issue see UBL 2013, 192, 198-199, regarding the iaculum: UBL 2013, 192-195, regarding the hasta: UBL 2013, 198-200. 
pose. There are examples that cross arrangement of hindlegs propped on the ground (not lifted for stride) were occasionally used on more dynamic, e.g. jumping scenes. ${ }^{8}$ The motion of the horseman aiming his weapon adds a certain grade of mobility to the scene. On the present fragment the traces of neither the crupper (postilena) nor the occasional accompanying straps or harness junctions (phalerae) are visible, as these details may have been most likely painted. ${ }^{9}$ Due to the fragmentary state of the depiction it is not possible to observe anything about the saddle (stratum/sella/ephippium) nor the shabrack (tapetum).

The horseman of the main scene depicts the man the tombstone was dedicated to, carrying evidently an assault weapon (hasta/iaculum). The way the relief field was arranged rules out the scene being a hunting scene. In case of a hunting scene, the large empty space behind the hunter would be inadequate, as hunting scenes the rendering would show the hunting and hunted animals (hunting dog, hare, big game) and the landscape in the background. The possibility of a civilian deceased depicted as a mounted hero can also be excluded. Heroes are depicted in a canonical manner: the cape (chlamys) of the horseman is an important element of the scene, which flutters even when the horse is not galloping, but there is no sign of the chlamys on the fragment from Bölcske. One can neither assume a stableboy (calo) leading the horse on the lost right side of the relief field as the weapon would be pointed against him. ${ }^{10}$

The rider thus is most likely a soldier. Tombstones raised for cavalrymen mention active or re-enlisted soldiers, while the gravestones of veterans depicted with horses and weapons tend to display hunting scenes. Such gravestones depicting cavalrymen comprise a significant portion of the rich funerary material of Pannonia. ${ }^{11} \mathrm{Cav}-$ alrymen are, however, often depicted in ancillary scenes, in the narrow frame between the main field and the inscription field or directly below the inscription. Riders depicted in the main field can be considered a rarity in Pannonia. The scale, composition, arrangement, workmanship and the field framing of the stelae of T. Flavius Bonio from Buda and Cusides from Dunapentele (present-day Dunaújváros), both depicting a cavalryman in the main field, show relation to the gravestone of Bölcske, and a number of researchers assumed they were produced in the same workshop. ${ }^{12}$ László Barkóczi went further in assuming that the same hand would have carved the inscriptions for the gravestones of Bonio and Cusides. ${ }^{13}$ Mathilde Schleiermacher, who established a typology for rider gravestones on the basis of their architectural forms, classified these two stelae to the group Typ II $1 \mathrm{~b}$ : aedicula, gable-topped, with reduced architectural form. ${ }^{14}$ Among the scenes of Pannonian rider gravestones, the depiction of Terso's funerary stela, recovered at Nagytétény, shows the closest stylistic relation to the rendering of this fragment from Bölcske. In terms of elaboration, Terso's gravestone is also related to the stelae of Bonio and Cusides. ${ }^{15}$ All three persons named on these gravestones were serving in the ala Frontoniana.

The inscription was carved into an independent field, bordered by a double profiled frame. The current dimensions of this fragment are $(23.5) \times(27.5) \mathrm{cm}$. Two incomplete rows survived of the inscription. Traces of guidelines drawn by the ordinator can be observed both above and below the first line. The centering of the second row attests the further careful design (ordinatio) of the inscription. The deeply carved and demanding capital letters are $7.5 \mathrm{~cm}$ (v. 1) and $5.5 \mathrm{~cm}$ (v. 2) high respectively. The cross sections of the letters are triangular with bevelled incisions. No traces of paint were discovered in the letters' base.

$$
\begin{aligned}
& \text { CRIṢ[- - - ] } \\
& \text { F }^{\circ} \mathrm{C}[---] \\
& \text { - - - - - }
\end{aligned}
$$

\footnotetext{
${ }^{8}$ Lupa 15803 (Mainz), 15523 (Bonn), 6249 (Augsburg), 6250 (Augsburg), EDCS-07800360 (Gloucester).

${ }^{9} \mathrm{O}$. Harl successfully reconstructed the colours of an rider scene on a stela from Vindobona. The horse was left unpainted, while the sculpted saddle was coloured grey, the breast collar, crupper, stirrup leathers and harness junctions had a red colour. Javelins and shield were also painted red: HARL 1978, 76-77. For the colour reconstruction of a rider scene of the Rhine region see: BOPPERT 1992, 160-161.

${ }^{10}$ For a summary on hunters, riders and stablemen of Pannonian funerary monuments see: GÁSPÁR 2016, 99-103.

${ }^{11}$ The finds were collected and systematized by: BURGER 1956; BARKÓCZI 1996.
}

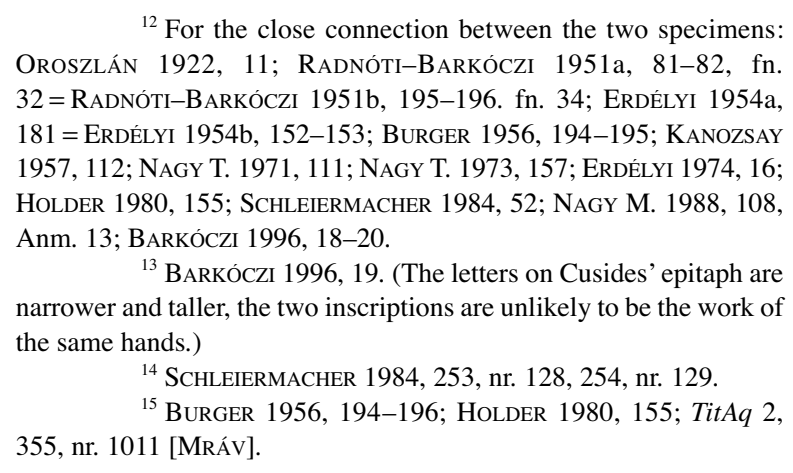

${ }^{12}$ For the close connection between the two specimens: OROSZLÁN 1922, 11; RADNÓTI-BARKÓCZI 1951a, 81-82, fn. 32 = RADNÓTI-BARKÓCZI 1951b, 195-196. fn. 34; ERDÉLYI 1954a, 181 = ERDÉLYI 1954b, 152-153; BURGER 1956, 194-195; KANOZSAY 1957, 112; NAGY T. 1971, 111; NAGY T. 1973, 157; ERDÉLYI 1974, 16; Holder 1980, 155; SCHLEIERMACHER 1984, 52; NAGY M. 1988, 108, Anm. 13; BARKÓCZI 1996, 18-20.

${ }^{13}$ BARKóCZI 1996, 19. (The letters on Cusides' epitaph are narrower and taller, the two inscriptions are unlikely to be the work of the same hands.)

${ }^{14}$ SChleiermacher 1984, 253, nr. 128, 254, nr. 129.

${ }^{15}$ Burger 1956, 194-196; Holder 1980, 155; TitAq 2, 355, nr. 1011 [MRÁv].

Acta Archaeologica Academiae Scientiarum Hungaricae 71, 2020 

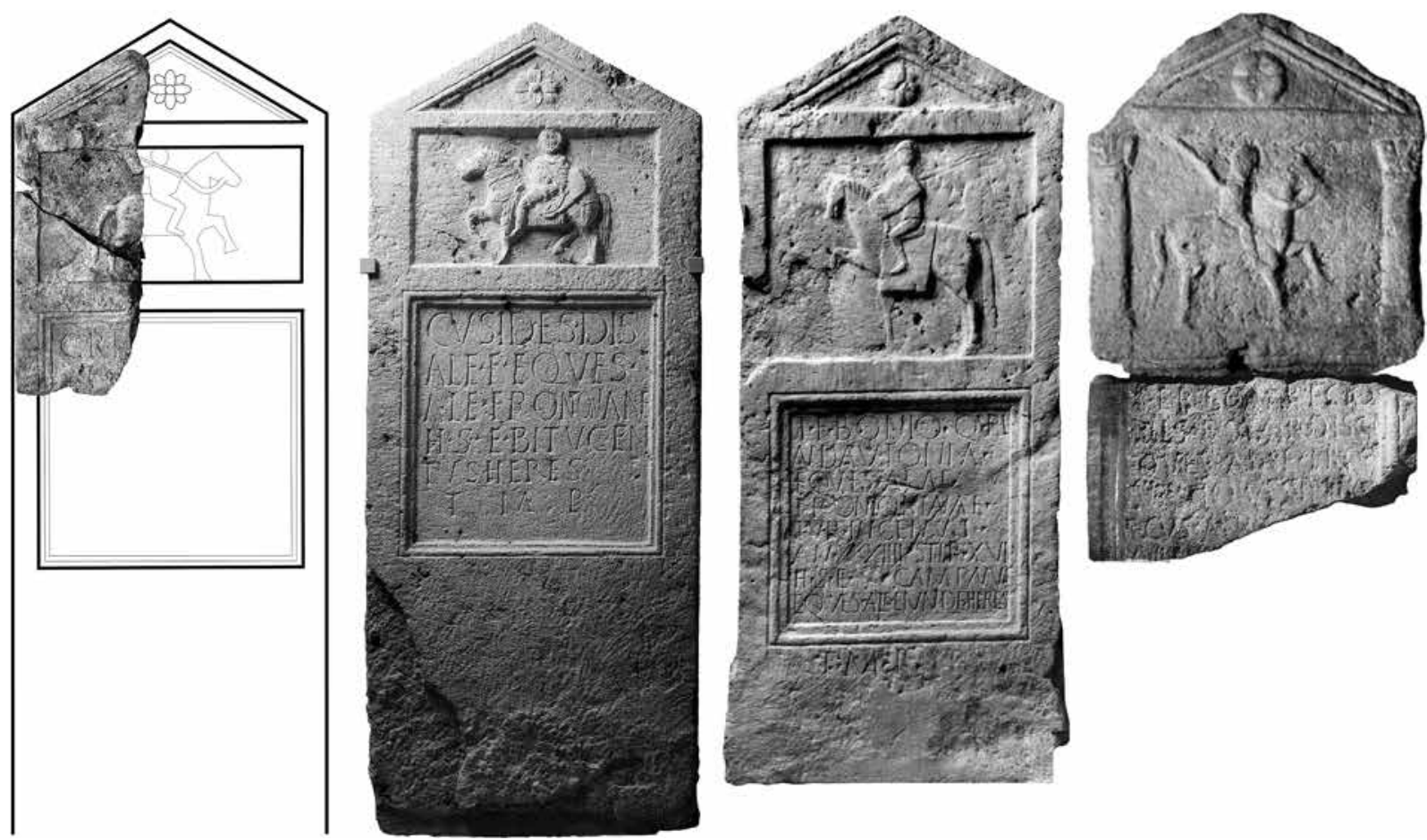

Fig. 2. Reconstruction of the gravestone from Bölcske (reconstruction: E. Szabó), along the stelae of Cusides, Bonio and Terso: Lupa 3560 (inv.n. MNM 97.1913.), Lupa 2726 (inv.n. MNM RD 169.), Lupa 2782 (inv.n. MNM 56.1911.3.=62.54.1.) (photo: O. Harl)

Palaeography of individual letters:

v. 1:

- C: Slightly recurving terminals, thick letter with a nigh 1:1 proportion. Its serifs extend to both directions in obtuse angles.

- R: Classic wide, quasi quadrata formed letter with an orderly rounded off eye, which connects to the stem slightly above the middle. The long, curved spur extends to the baseline, skimming the foot serif of the subsequent I letter.

- I: Precisely carved vertical hasta with horizontal head and foot serifs. Its foot serif touches the spur of the previous letter $\mathrm{R}$.

- S: Only a section of the upper bowl and the foot serif survived.

v. 2:

- F: The width and height of the letter are in $1: 2$ proportion. The middle arm meets the stem in the middle. The upper and lower arms are of approximately equal length, both are terminated with serifs.

$-\infty$ : Large hedera shaped separator (interpunctio) carved deeper, outlined with a long, right curving footstalk. Hedera shaped separators are less widespread in Pannonia than small triangular carvings (punctum triangulare), the former appear more often on sophisticated inscriptions. They occasionally appear on inscriptions with diverse separators. The use of hederae appears to be an important indicator of social status: in the epigraphic material of Aquincum only honestiores and soldiers use them. ${ }^{16}$

- $\mathrm{C} / \mathrm{G} / \mathrm{O} / \mathrm{Q}$ : A rounded, wide, quadrata type letter comprised of curves.

\footnotetext{
${ }^{16}$ Their use culminates in the $2^{\text {nd }}$ century, almost half of the total occurrences are dated to this period: FeHÉR-Kovács 2018, $128-129$.

Acta Archaeologica Academiae Scientiarum Hungaricae 71, 2020
} 
The surviving four letters of the first line form likely the name of the deceased, probably in nominative, written unabbreviated: Crispus/Crispinus/Crispinianus? ${ }^{17}$ Female name variants can be excluded due to the nature of the rider scene. The name of the defunct was followed by the filiatio, thus the first line terminated with the father's name in genitive. The first letter of the centered second row is a sigla, the interpretation of which is unanimously $f(i l i u s)$. His single name and filiatio indicate the deceased being a peregrinus. ${ }^{18}$ The rounded letter fragment $(\mathrm{C} / \mathrm{G} / \mathrm{O} / \mathrm{Q})$ beginning the second word of the second line offers several possibilities. Recording the origin (origo) seems to be the most plausible via either a name referring to the tribe (e.g. C[olapianus], C[ornacatus]... etc.) ${ }^{19}$ or in $c$ [ivis ...] form ${ }^{20}$ denoting in which civitas peregrina the deceased was originating. Another possibility is that the letter was intended to the recording of a junior officer rank (principales) ${ }^{21}$ of the cavalry: c[ustos armorum], ${ }^{22}$ $o$ [ptio], c[urator], or c[ornicularius]. The subsequent part of the inscription showed most likely the name of the mounted unit (ala), its smaller detachment (turma), followed by age, service years, the names of the heirs and some ending formulae.

$$
\begin{aligned}
& \text { Criș[pus (?) - - - ] } \\
& \text { f(ilius) Cִ [-- -] } \\
& \text { - . . . - }
\end{aligned}
$$

In summary, we can state that the recently discovered fragmentary stela from Bölcske is closely related to three further tombstones of cavalrymen from the ala Frontoniana in several aspects. The proportion, structure (freestanding tympanon, fields conjoined by unadorned frames) and arrangement (tympanon - relief field - inscription field) are very similar, as well as the framing of individual fields (double profiled frame on the even edges of the tympanon and around the inscription field), and the rider scene in the depressed relief field, where the relief does not fill entirely the available space.

With the close relation between the four gravestones, one can carefully conclude that the owner of the Bölcske gravestone was plausibly serving or being re-enlisted as a horseman with the ala Frontoniana. His comrades (or his heir selected amongst his comrades) have set his tombstone, which was made along the design standards preferred by the unit. This hypothesis is further supported by a special detail of the composition of the Bölcske gravestone, as the assault weapon was partially carved onto the frame of the relief field, which appears to be a custom specific to the Rhine region in the $1^{\text {st }}$ century AD. ${ }^{23}$ The ala Frontoniana was transferred, following a brief Dalmatian detour, ${ }^{24}$ to Pannonia from the Rhine, where its soldiers became probably familiar with local designs. The ala Frontoniana must have played a stimulating role in Pannonian stone-working by transferring this rider scene type from the Rhine region. ${ }^{25}$

Based on the three analogous funerary stelae, the middle of the tympanon of the Bölcske gravestone was likely adorned with a rosette. ${ }^{26}$ The relief field is to be reconstructed as a depiction of a calmly pacing horseman. Similar to his three comrades, this cavalryman wore a short chainmail (lorica hamata) which was introduced to

${ }^{17}$ Crispus: common in Northern Italy and western provinces, slightly more widespread east of Italy. Its spread in Illyricum is due to the unique naming tradition of the army. It is a name preferred among the peregrini of Pannonia (Mócsy 1959, 32, 60, 117, 171; Mócsy 1984, 210, 213, Abb. 20; Mócsy 1985, 49-52. fig. 32). Crispinus: common in Northern Italy, not so much in western provinces, it was a ,common” name concentrated in the Danubian provinces (Mócsy 1959, 171; Mócsy 1984, 216; MócSY 1985, 63). Crispinianus: occurs in Northern Italy, it is a rather uncommon name (BARKÓCZI 1964, 310). Regarding the name Crispus and derivate forms: KAJANTO 1965, 223. For their occurrence see: LỏRINCZ ed. $1999,85$.

${ }^{18}$ Mócsy 1959, 115-117.

${ }^{19}$ Terso (scordiscus) and Bonio (Andautonia) came from the Sava region and were recruited locally. The name of Cusides, his father and his heir are all Thracian (Mócsy 1959, 166, 171, 257). He was recruited either in Dalmatia (VISY 2016, 200) or Pannonia (ALFÖLDI 1944, 54-55).
${ }^{20}$ The literary civis in Pannonia is more commonly used in cives form: FEHÉR 2007, 233.

${ }^{21}$ Mounted junior officers often display the term eques, their unit (including their turma) and their rank in this sequence on epitaphs: SCHLEIERMACHER 1984, 17.

${ }^{22}$ Terso who was as a custos armorum alae also appears with a javelin (iaculum) in his right on his Campona gravestone. The iaculum was the equipment of both common horsemen and warrant officers: UBL 2013, 194-195.

${ }^{23}$ Lupa 15525 (Bonn), 15527 (Bonn), 15528 (Bonn, eques alae Frontonianae!), 20697 (Köln), 16780 (Worms), 16781 (Worms), 15806 (Mainz), 15811 (Mainz), 15836 (Mainz), EDCS-62301397 (Koenigshoffen), SCHLEIERMACHER 1984, 217-218, nr. 96 (Koenigshoffen).

${ }^{24}$ ALFÖLDY 1962, $262=$ ALFÖLDY 1987, 243-244.

${ }^{25}$ ERDÉLYI 1954a, 181 = ERDÉLYI 1954b, 153; BURGER 1956, 195; BOPPERT 1992, 60.

${ }^{26}$ The rosette on Cusides' stela has eight petals, the one on Terso's and Bonio's has four.

Acta Archaeologica Academiae Scientiarum Hungaricae 71, 2020 

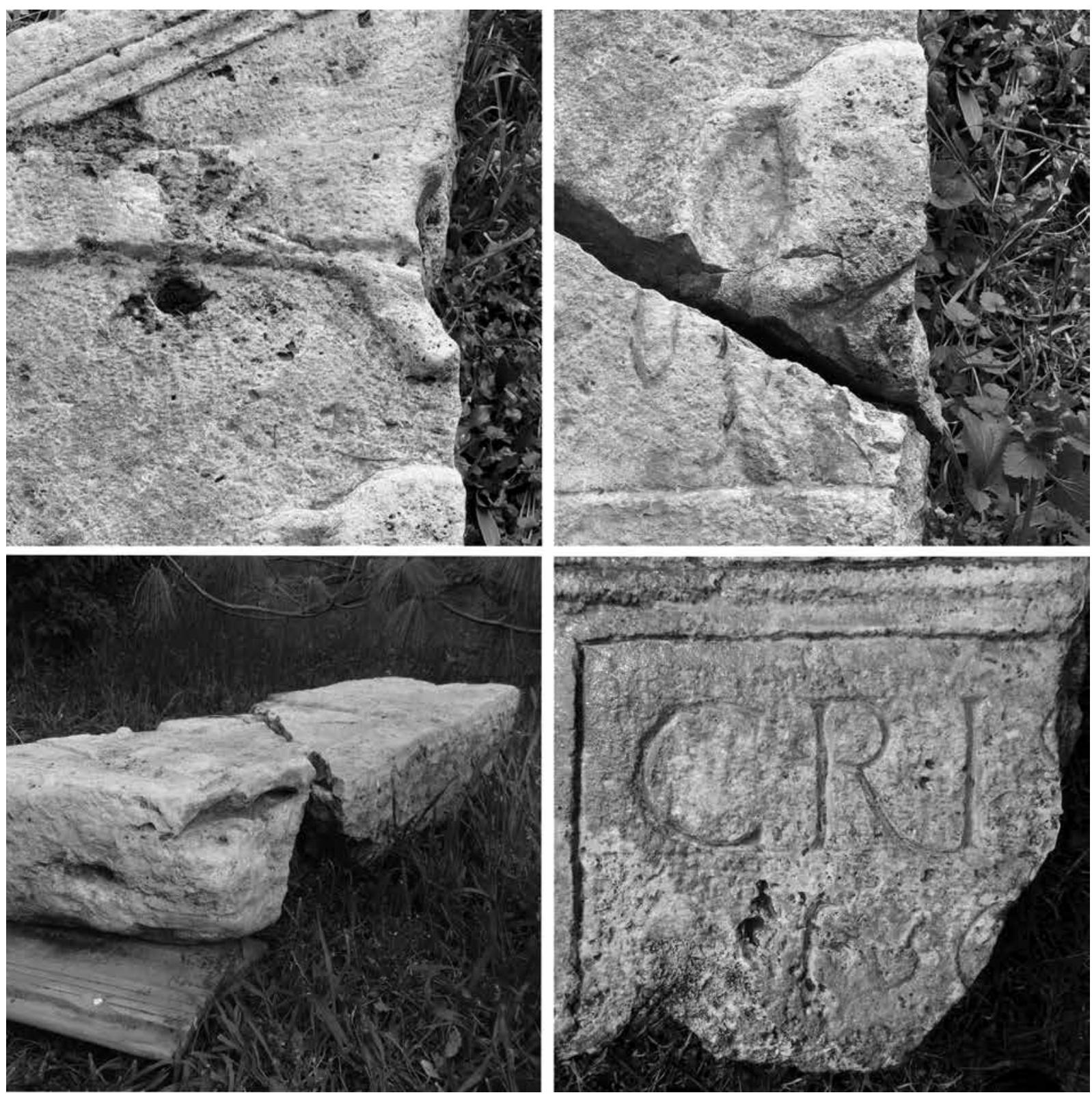

Fig. 3. Details of the gravestone fragment from Bölcske (photo: E. Szabó )

mounted units in the $2^{\text {nd }}$ century and was generally used regardless of rank. ${ }^{27}$ The handheld assault weapon, similarly to the ones of Terso and Bonio, ${ }^{28}$ was a javelin (iaculum).

The similar phrasing of the inscriptions on the three analogous stelae suggests that the finishing formulae on the Bölcske epitaph be HSE and TMP contemporaneously. ${ }^{29}$

One can presume that there was an unadorned, roughly hewn footing below the inscription field. The total width and height of the stela can be presumed being $90 \mathrm{~cm}$ and 200-210 cm respectively. It is likely that the gravestone was originally not set up at Bölcske, because the three analogous stelae were found at other locations: the

${ }^{27}$ Cusides and Bonio were equites alae, Terso was custos armorum alae and they all wore short chainmail. For lorica hamata: UBL 2013, 40-56 (Regarding the three soldiers of the ala Frontoniana: UBL 2013, 41, 54; GÁsPÁr 2016, 491, 495, 508).
${ }^{28}$ UBL 2013, 193, nr. 62, nr. 55.

${ }^{29}$ FITZ 1962, 33, nr. 2, Bonio, 34, nr. 19, Cusides. The parts following the HSE on Terso's epitaph are missing.

Acta Archaeologica Academiae Scientiarum Hungaricae 71, 2020 
The phrasing of the inscriptions of Crispus (?), Terso, Cusides and Bonio

\begin{tabular}{|c|c|c|c|c|}
\hline nomen & Cris[pus (?) & Terso & Cusides & T(itus) F(lavius) Bonio \\
\hline tribus & & & & Qu(i)ri(na tribu)। \\
\hline filiatio & - - -j|f(ilius) & Preciolnis f(ilius) & Dislal(a)e f(ilius) & \\
\hline origo & $c[---]$ & Scordiscus 1 & & Andautonia $\mathrm{I}$ \\
\hline eques & $\ldots$. & eques & eques I & eques \\
\hline ala & & alae Fron(tinianae) I & al(a)e Frontonian(a)e I & alae $\mid$ Frontonianae $\left.\right|^{5}$ \\
\hline turma & & tur(ma) Lobasini & & tur(ma) Ingenui I \\
\hline principalis & & $\left.a\right|^{5}$ r(morum) cus(tos) & & \\
\hline anni & & an(norum) $X X[X--$ & & an(norum) XXXIIII \\
\hline stipendia & & stip(endiorum)] $\mid X V I$ & & stip(endiorum) $X V I \mid$ \\
\hline$H S E$ & & $h(i c)[s($ itus $) e(s t)$. & $h($ ic) $s$ (itus) e(st). & $h($ ic) $s($ itus $) e(s t)$. \\
\hline heres & & $\ldots \ldots$ & Bitugen|'tus heres I & Campanus $\{S\} \mid$ eques al (a)e eiunde $(!)$ heres $\|$ \\
\hline$T M P$ & & & t(itulum) m(emoriae) p(osuit). & t(itulum) m(emoriae) p(osuit). \\
\hline
\end{tabular}

Bonio gravestone was recovered from Buda(?) amid unclear circumstances,${ }^{30}$ the Terso gravestone was extracted from a Modern wall at Nagytétény, ${ }^{31}$ while the Cusides gravestone was reused as a cover of a Late Roman grave in Dunapentele. ${ }^{32}$ Stones from both the Gellért Hill in Budapest and Nagytétény were transported to the construction site of the Late Roman bridgehead at Bölcske. ${ }^{33}$ In medieval times, Roman monuments from the nearby Dunapentele were hauled to Bölcske for constructions. ${ }^{34}$

Regarding this, Szentandráspuszta should have been a secondary or successive location of our fragment. The primary location of the gravestone cannot be deducted from the dislocation history of the ala Frontoniana, as the garrison of the unit could not be located so far. The possible locations are either Aquincum, Campona or Intercisa. Consequently, the gravestone must have been produced while the ala was stationed in north-east Pannonia.

A more precise dating could be provided by the chronology of the stonemason's workshop. Although there are minor differences in the style of the four rider images, one cannot exclude that they were all produced by the

Dislocation history of the ala Frontoniana in north-east Pannonia based on academic research

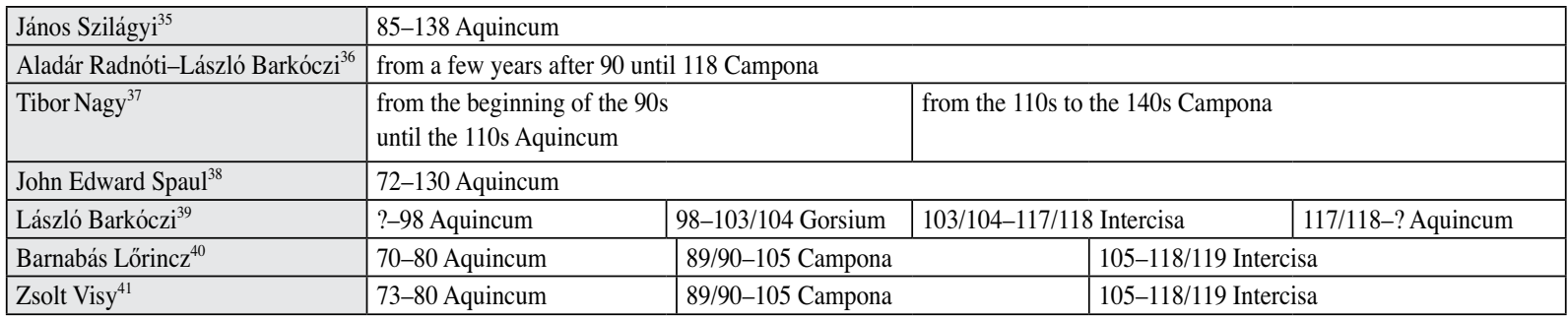

${ }^{30}$ TitAq 2, 98-99, nr. 616. Zs. Mráv does not comment on the Buda findspot. Cf. the comment in the Lupa database: "im Bildarchiv der Ung. Akad. d. Wiss. wird das Neg. Nr. 70671 unter Fundort Gellertberg geführt". Based on the incorrect data of F. Rómer and E. Desjardins (DESJARDINS-RóMER 1873a, 82, nr. 169) which was corrected in the subsequent Hungarian edition (DESJARDINS-RÓMER 1873 b, 92-93, nr. 169), a presumption was made that the gravestone was transferred to the National Museum from the Migazzi Collection in Vác: NAGY T. 1954,107 , fn. $37=$ NAGY T. 1956, 54, fn. 43. The gravestone is not listed in the collection of Cardinal Migazzi: TragOR 1912, 61-62. Referring to A. Schober, D. Gáspár mentions Törökbálint as a possible findspot (GÁSPÁR 2016, 508, nr. 477), although Schober published the find as of unknown provenance (Törökbálint refers to the preceding inscription): SCHOBER 1923, 53, nr. 112. Referring to T. Nagy, D. Gáspár also lists Dunaújváros as a possible origin, although the cited works of T. Nagy do not contain such information.
${ }^{31}$ TitAq 2, 355, nr. 1011 [Mráv].

${ }^{32}$ VISY 2016, 199, nr. 182.

${ }^{33}$ BesZÉdES-MrÁv-Tóth 2003, 103 = BESZÉdES-MrÁVTóTH 2009, 121.

${ }^{34}$ MrÁv 2016, 48-50.

${ }^{35}$ SZILÁGYi 1941, 234.

${ }^{36}$ RADNÓTI-BARKÓCZI 1951a, 81-83, 100, 103 = RADNÓTIBARKÓCZI 1951b, 195-197, 220, 224.

${ }^{37}$ NAGY T. $1954,106-108=$ NAGY T. 1956, 52-55;

NAGY T. 1971, 111; NAGY T. 1973, 157.

${ }^{38}$ SPAUL-CiCHORIUS 1994, 117-119.

${ }^{39}$ BARKóCZI 1996, 20-21, 24, 26.

${ }^{40}$ LŐRINCZ 2001, 26, nr. 29; LŐRINCZ 2010, 259.

${ }^{41}$ VISY 2003, 147. 
same workshop, and the slight differences are due to the different renderings by the artisans (quadratarius). The carver of the inscriptions (scriptor titulorum) was likely not the same artisan as well. Based on the independent observations of Gizella Erdélyi ${ }^{42}$ and Tibor Nagy, ${ }^{43}$ a change in gravestone proportions $(1: 2)$ was introduced by the workshop of legio X Gemina which was relocated to Aquincum at the end of 101 or the beginning of 102, and it could have been the model for the gravestones of Bonio and Cusides. The latter researcher considered the two gravestones being products of the ala's workshop, to be localized in the vicus of the auxiliary fort at Budapest Víziváros which was deserted after the ala moved to Campona after 106. Thus, the stela is to be dated to 104/105. In his opinion, the rider's figure of the Terso gravestone, set in a pillared niche, is the product of the Campona workshop. ${ }^{44}$ L. Barkóczi ${ }^{45}$ was possibly making a mistake in presuming that the workshop which produced the Cusides and Bonio gravestones would have been at Gorsium. ${ }^{46}$

Considering unit history, arguments of style analysis and palaeographical reasons, ${ }^{47}$ the Bölcske gravestone should also be dated to the early reign of Emperor Trajan.

\begin{tabular}{|c|c|c|c|}
\hline & Stela groups & Workshop location & Dating \\
\hline \multirow[t]{2}{*}{ Aladár Radnóti-László Barkóczi ${ }^{49}$} & Cusides, Bonio, Terso & Aquincum & $100-110$ \\
\hline & Flavus & & beginning of the $2^{\text {nd }}$ century \\
\hline \multirow[t]{2}{*}{ Gizella Erdélyi $^{50}$} & Cusides, Bonio & vicinity of Aquincum & beginning of the $2^{\text {nd }}$ century \\
\hline & Mulsus-Litugenus & autochthonous workshop & first decades of the $2^{\text {nd }}$ century \\
\hline Alice Sz. Burger ${ }^{51}$ & Cusides, Bonio, Terso & Aquincum & Flavian-Trajanic period \\
\hline \multirow[t]{3}{*}{ Tibor Nagy ${ }^{52}$} & Cusides, Bonio & \multirow{2}{*}{$\begin{array}{l}\text { Aquincum } \\
\text { (ala workshop at Víziváros) }\end{array}$} & $104-105$ \\
\hline & Mulsus-Litugenus, Flavus ${ }^{53}$ & & before 106 \\
\hline & Terso & Campona & from after 106 until the $140 \mathrm{~s}$ \\
\hline \multirow[t]{3}{*}{ László Barkóczi ${ }^{54}$} & Mulsus-Litugenus, (Adinamo) $)^{55}$ & Gorsium & $98-103 / 104$ \\
\hline & Cusides, Bonio & Gorsium & $103 / 104-106$ \\
\hline & Flavus & & $120-130$ by earliest \\
\hline
\end{tabular}

\section{REFERENCES}

ALFÖLDI 1944

ALFÖLDY 1962

ALFÖLDY 1987

BARKÓCZI 1964

BARKÓCZI 1996
= A. ALFÖLDI: Zu den Schicksalen Siebenbürgens im Altertum. Ostmitteleuropäische Bibliothek 54. Budapest 1944.

= G. AlföLDY: Die Auxiliartruppen der Provinz Dalmatien. ActaArchHung 14 (1962) 259-296.

= G. AlFöLDY: Die Auxiliartruppen der Provinz Dalmatien. In: Römische Heeresgeschichte: Beiträge 1962-1985. Hrsg.: M. Speidel. Mavors Roman army researches 3. Amster 1987, 239-297.

$=$ L. BARKÓCZI: The population of Pannonia from Marcus Aurelius to Diocletian. ActaArchHung 16 (1964) 257-356.

= L. BARKÓCZI: Grabmäler frühzeitiger Auxiliar-Soldaten aus Gorsium und Intercisa (Dunaújváros). In: Festschrift für Jenő Fitz. Hrsg.: Gy. Fülöp. IKMK B 47. Székesfehérvár 1996, 14-27.
${ }^{42}$ ERdÉlYi 1954a, 181 = ERDÉLYI 1954b, 152-153.

${ }^{43}$ NAGY T. 1954,106 , fn. $26=$ NAGY T. $1956,52-53$, fn. 32. See also: NAGY T. 1971, 110-111, 113; NAGY T. 1973, 157.

${ }^{44}$ NAGY T. $1971,111$.

${ }^{45}$ BARKÓCZI 1996, 20-21, 24, 26.

${ }^{46}$ The counterarguments of B. Lörincz are convincing: LŐRINCZ 2010, 256-257.

${ }^{47}$ FEHÉR-KovÁcs 2018, 27-30, 36-38, 41-43, 51-54, $128-129$.

${ }^{48}$ Mulsus-Litugenus (Lupa 3576), Adinamo (Lupa 3510), Cusides (Lupa 3060), Bonio (Lupa 2716), Terso (Lupa 2782), Flavus (Lupa 2792). Pannonian inscriptions related to ala Frontoniana: LŐRINCZ 2001, Kat. Nr. 3, 5-6, 9, 13-16, 209-218.

${ }^{49}$ RADNÓTI-BARKÓCZI 1951a, 81-83, 100, 103 = RADNÓTIBARKÓCZI 1951b, 195-197, 220, 224.
${ }^{50}$ ERdélyi 1954a, 181-182 = ERdÉLYi 1954b, 152-154.

${ }^{51}$ BURGER 1956, 194-195.

${ }^{52}$ NAGY T. 1954, 106-108 = NAGY T. 1956, 52-55; NAGY T. 1971, 111; NAGY T. 1973, 157.

${ }^{53}$ T. Nagy dates the Flavus' stela to the $120-130$ s the earliest in his early works: NAGY T. 1954, 106-107 = NAGY T. 1956, 53-54.

${ }^{54}$ BARKóczi 1996, 20-21, 24, 26.

${ }^{55}$ No cavalry unit name is shown on Adinamo's stela (accepting T. Nagy's interpretation the defunct was a soldier of the cohors Thracum): VISY 2016, 119-120, nr. 109. Based on style analysis alone, L. Barkóczi relates it to the Mulsus-Litugenus monument and thus relates the deceased to the ala Frontoniana. G. Erdélyi found no correlation between the two specimina: ERDÉLYI 1954a, 181-182 = ERDÉLYI 1954b, 153-154. 
BESZÉDES-MRÁv-TóTH 2003

BESZÉDES-MrÁv-TóTH 2009

BOPPERT 1992

BURGER 1956

DESJARDINS-RÓMER 1873a

DESJARDINS-RÓMER $1873 \mathrm{~b}$

EDCS

ERDÉLYI 1954a

ERDÉLYI 1954b

ERDÉLYI 1974

FEHÉR 2007

FEHÉR-KovÁCs 2018

FITZ 1962

GÁSPÁR 2016

HARL 1978

HOLDER 1980

KAJANTO 1965

KANOZSAY 1957

KovÁcs 2014

LŐRINCZ 2001

LŐRINCZ 2010

LŐRINCZ ed. 1999

Lupa

Mócsy 1959

Mócsy 1984

MóCSY 1985

Mráv 2016

NAGY M. 1988

NAGY T. 1954
= J. BeszÉdes-Zs. MrÁv-E. TóTh: Die Steindenkmäler von Bölcske. Inschriften und Skulpturen. Katalog. In: Bölcske. Römische Inschriften und Funde. Hrsg.: Á. Szabó, E. Tóth. Libelli archaeologici, Ser. nov. 2. Budapest 2003, 103-218.

= J. BESZÉDES-Zs. MRÁv-E. TóTH: Bölcskei kőemlékek: Feliratok és faragványok (Stone monuments of Bölcske: inscriptions and sculptures). In: A bölcskei kikötőerőd. Római kori feliratok és leletek a Dunából. Ed.: A. Gaál. Szekszárd 2009, 121-254.

= CSIR (Corpus signorum imperii Romani) : Deutschland. 2.: Germania superior. 5.: W. BOPPERT: Militärische Grabdenkmäler aus Mainz und Umgebung. Mainz 1992.

= A. Sz. Burger: Lovas-sírkövek Pannóniában az i.u. I. századból (Reitergrabsteine aus Pannonien im I. Jahrhundert n. u. Z.). ArchÉrt 83 (1956) 191-197.

= E. Desjardins-F. Rómer: Monuments épigraphiques du Musée National Hongrois. Acta Musei Nationalis Hungarici. Buda-Pest 1873.

= E. Desjardins-F. Rómer: A Magyar Nemzeti Muzeum római feliratos emlékei = Inscriptiones monumentorum Romanorum eiusdem Musei Nationalis in Budapest. Acta Nova Musei Nationalis Hungarici 1. Budapest 1873.

= Epigraphik-Datenbank Clauss / Slaby: http://db.edcs.eu

= G. ERDÉLYI: Steindenkmäler. In: L. Barkóczi-G. Erdélyi et al.: Intercisa (Dunapentele-Sztálinváros). Geschichte der Stadt in der Römerzeit. I. ArchHung 33. Budapest 1954, 169-231.

= G. ERDÉLYI: Köemlékek (Stone monuments). In: L. Barkóczi-G. Erdélyi et al.: Intercisa (Dunapentele-Sztálinváros) története a római korban. I. ArchHung 33. Budapest 1954, 143-193.

$=$ G. ERDÉLYI: A római kőfaragás és kőszobrászat Magyarországon [Roman Stone Carving and Sculptures in Hungary]. Ed. by D. Gáspár. Apollo könyvtár 5. Budapest 1974.

= B. FeHÉR: Pannonia latin nyelvtörténete [The History of the Latin Language in Pannonia]. Fontes Pannoniae antiquae 3. Budapest 2007.

= B. FEHÉR-P. KovÁCs: Palaeographia Aquincensis. Aquincum görög és latin feliratainak paleográfiája (Palaeographia Aquincensis. Palaeography of Greek and Latin Inscriptions of Aquincum). Budapest 2018.

= J. FITZ: Titulum memoriae posuit. Alba Regia 2-3 (1962) 33-48.

= D. GÁsPÁR: Pannoniai síremlékek I-III. Római kori halottkultusz a mai Magyarország területén [Grave Monuments in Pannonia. I-III. Ancient Roman Cult of the Dead on the Territory of Presentday Hungary]. Bivio 4. Budapest 2016.

$=$ O. HARL: Der Grabstein des T. Flavius Draccus. In: Classica et provincialia. Festschrift Erna Diez. Hrsg.: G. Schwarz, E. Pochmarski. Graz 1978, 73-81.

$=$ P. A. Holder: Studies in the Auxilia of the Roman Army from Augustus to Trajan. BAR IntSer 70. Oxford 1980.

= I. KAJANTO: The Latin Cognomina. Societas Scientiarum Fennica, Commentationes humanarum litterarum 36/2. Helsinki 1965.

= M. KANOZSAY: Egy római síremlék Iszkaszentgyörgyről (Un monument funéraire romain d'Iszkaszentgyörgy). AT 4 (1957) 107-115.

= P. KovÁcs: Egy újabb római felirat Bölcskéről (A newer Roman inscription from Bölcske). In: Felirattani újdonságok 2014-ben. Eds: P. Kovács, B. Fehér. Studia epigraphica Pannonica 6. Budapest 2014, 51-53.

= B. LỎRINCZ: Die römischen Hilfstruppen in Pannonien während der Prinzipatszeit. I.: Die Inschriften. Wiener archäologische Studien 3. Wien 2001.

= B. LŐRINCZ: Zur Militärgeschichte der Donauprovinzen des Römischen Reiches I. Hungarian polis studies 19. Budapest-Debrecen 2010.

= B. LŐRINCZ (ed.): Onomasticon provinciarum Europae Latinarum. 2.: Cabalicius-Ixus. Wien 1999.

$=$ F. HARL-O. HARL: http:/lupa.at (Bilddatenbank zu antiken Steindenkmälern)

= A. Mócsy: Die Bevölkerung von Pannonien bis zu den Markomannenkriegen. Budapest 1959.

= A. Mócsy: Lateinische Cognomina als Geschichtsquelle: Zwei Typen der provinzialrömischen Kultur. ActaArchHung 36 (1984) 197-222.

= A. Mócsy: A római név mint társadalomtörténeti forrás: akadémiai székfoglaló, 1983. április 6 . (Roman Names as Sociohistorical Sources, Academic Inaugural, $6^{\text {th }}$ of April 1983). Értekezések, emlékezések. Budapest 1985.

= Zs. Mráv: Új adatok Pannonia Inferior Commodus-kori burgus- és praesidium építési felirataihoz (Neue Daten zu den Bauinschriften von burgi und praesidia in Pannonia Inferior aus der Zeit von Commodus). FolArch 57 (2016) 35-60.

= M. NAGY: Die nordpannonische Gruppe der mit sog. Astralsymbolen verzierten Grabsteine. ComArchHung 1988, 93-111.

$=\mathrm{T}$. NAGY: Az albertfalvai katonai diploma. I-II (The military diploma of Albertfalva. I-II). ArchÉrt 81 (1954) 10-32, 104-118. 
NAGY T. 1956

NAGY T. 1971

NAGY T. 1973

OROSZLÁN 1922

PÉTERFI 1993

RADNÓTI-BARKÓCZI 1951a

RADNÓTI-BARKÓCZI 1951b

SCHLEIERMACHER 1984

SCHOBER 1923

SOPRONI 1990

SPAUl-CICHORIUS 1994

SZABÓ-SZÉCSI 1994

SZILÁGYI 1941

TitAq 2

TrAgOR 1912

UBL 2013

UDVARI 1994

VISY 2000

VISY 2003

VISY 2016
$=$ T. NAGY: The military diploma of Albertfalva. ActaArchHung 7 (1956) 17-71.

$=$ T. NAGY: Köfaragás és szobrászat Aquincumban (Taille de pierre et sculpture à Aquincum). BudRég 22 (1971) 103-160.

= T. NAGY: Római kor (The Roman Age). In: Budapest története. I.: Budapest története az őskortól az Árpád-kor végéig. Ed.: L. Gerevich. Budapest 1973, 83-184.

= Z. OROSZLÁN: Kiadatlan pannoniai provinciális kőemlékek a M. Nemzeti Múzeumban (Unpublished Pannonian provincial stone monuments in the Hungarian National Museum). ArchÉrt 39 (1922) 1-11.

= Zs. V. PÉTERFI: 48/2. Bölcske-Kövesszállás. RégFüz I/45 (1993) 32.

= A. RADNÓTI-L. BARKóCZI: Adatok Pannonia inferior II. századi hadrendjéhez (The distribution of troops in Pannonia Inferior during the $2^{\text {nd }}$ century A. D.). ArchÉrt 78 (1951) 78-107.

$=$ A. RADNÓTI-L. BARKóCZI: The distribution of troops in Pannonia Inferior during the $2^{\text {nd }}$ century A. D. ActaArchHung 1 (1951) 191-230.

= M. SCHLEIERMACHER: Römische Reitergrabsteine. Die kaiserzeitlichen Reliefs des triumphierenden Reiters. Abhandlungen zur Kunst-, Musik- und Literaturwissenschaft 338. Bonn 1984.

= A. SCHOBER: Die römischen Grabsteine von Noricum und Pannonien. SÖAI 10. Wien 1923.

$=\mathrm{S}$. SOPRONI: Előzetes jelentés a bölcskei késő római ellenerőd kutatásáról (Vorläufiger Bericht über die Erforschung der spätrömischen Gegenfestung in Bölcske). ComArchHung 1990, 133-142.

= J. E. H. Spaul-C. Cichorius: Ala: The Auxiliary Cavalry Units of the Pre-Diocletianic Imperial Roman Army. Andover 1994².

= G. SZABÓ-A. SzÉCSI: Bölcske határának régészeti lelőhelyei (Archaeological sites in the vicinity of Bölcske). In: Múlt és jelen Bölcskén. Régészeti, történeti, természettudományi és néprajzi kutatások, tanulmányok a falu életéből. Ed.: G. Szabó. Bölcskei tanulmányok 1. Bölcske 1994, 69-114.

= J. SZILÁGYI: Az aquincumi helyőrség csapattestei (Units garrisoned at Aquincum). TBM 9 (1941) 231-246.

= P. KovÁcs-Á. Szabó (cur.): Tituli Aquincenses. II.: Tituli sepulcrales et alii Budapestini reperti. Budapest 2010.

= I. TRAgor: A Váci Múzeum gyüjteményeinek leíró lajstroma (Descriptive Records of the Collections of the Museum of Vác). Vác 1912

$=$ H. UBL: Waffen und Uniform des römischen Heeres der Prinzipatsepoche nach den Grabreliefs Noricums und Pannoniens. Dissertation zur Erlangung des Doktorgrades an der philosophischen Fakultät der Univerität Wien, Juni, 1969. Austria antiqua 3. Wien-Graz 2013.

= G. UDVARI: Bölcske község földrajzi nevei a szájhagyomány alapján (Toponyms of Bölcske municipality based on oral tradition). In: Múlt és jelen Bölcskén. Régészeti, történeti, természettudományi és néprajzi kutatások, tanulmányok a falu életéböl. Ed.: G. Szabó. Bölcskei tanulmányok 1. Bölcske 1994, 399-430.

= Zs. VISY: A ripa Pannonica Magyarországon (The Ripa Pannonica in Hungary). Budapest 2000.

= Zs. VISY: The Ripa Pannonica in Hungary. Budapest 2003.

= Zs. VISY: Intercisa feliratai (Inscriptions of Intercisa). Pécs 2016.

Open Access. This is an open-access article distributed under the terms of the Creative Commons Attribution 4.0 International License (https:// creativecommons.org/licenses/by/4.0), which permits unrestricted use, distribution, and reproduction in any medium, provided the original author and source are credited, a link to the CC License is provided, and changes - if any - are indicated. (SID_1) 